\title{
Social Trust and Social Network in Iran
}

\author{
Mojdeh Kiani
}

\begin{abstract}
In this paper take a focus on the linkages between trust and social networks. The main purpose of this article is recognition of present status of social trust, concerning social network of men and women. This research has been done through survey method in Iran in 2011. Men and women over 18 mostly residents of Esfahan form the statistical community of this research. The results of multi regressive analysis show that the variables in the equation including effective social trust, network supportive, education and kind of job with other variables has the most effect on social trust and is kept in the equation. There is a significant difference between gender and social trust.
\end{abstract}

Index Terms-Social trust, social capital, social network, gender, network supportive.

\section{INTRODUCTION}

Trust is a kind of condition about probably actions of other people in the further. In some society people are more ready to trust and in another society people are lack of trust. Usually, the most important and general context for trust estimate capacity of trust its aim, that we consider it as whether "we can trust or no?" Usually we expose to different "rate of trust. This paper begins to explore the relationships between social trust and network by comparing their origins or sources. Social trust is a sociological concept, which refers to good relationships in society. Trust is one of the key elements of social capitals' recognition. Trust is risk, that is, both group and person know that the actions of one them affect the other.

People have been experienced trust in numerous contexts, such as within family, between and among friends, and colleagues, with organizations and institutions. Trust within the context of family differs from the trust in institutions and civil society. Organizational trust is more than simply the personal trust that exists between individuals based on experience [1]. It may be seem as deriving as well at least partly from the roles, rules, and structured relations of the organization [2].Granovetter [3] has focused that social relations are mainly responsible for the production of trust in economic life. He believes that trust is generated when agreements are "embedded" within a larger structure of personal relations and social networks (p. 488-493). Social structure is important not only for the formation of social capital but also for the generation of trust itself [4]. In addition to social relations, shared norms are a source of trust. In social network analysis, nodes (people) and ties(relationships between people) are the central analytic entities. In order to outline the structure of a social network,

Manuscript received October 19, 2012; revised November 20, 2012.

Mojdeh Kiani is with Department of Social Science, Payame Noor university, Tehran, Iran (e-mail: mjdhkiani@yahoo.com). the research population is asked sociometric questions such as "Whom would you choose as a friend?" or "Who would you best like working with?" While several statistical measures based on this information may be calculated in order to quantify the structure of social networks, the nature of the data material also has implications for the choice of network measures [5]. Giddens [6] defines trust as "confidence in the reliability of a person or system, regarding a given set of outcomes or events, where that confidence expresses a faith in the probity or love of another, or in the correctness of abstract principles." In this article the focus is on women's social networks and social trust in Esfahan(IRAN). Social network analysis is focused on uncovering the patterning of people's interaction. Network analysts believe that how an individual lives depends in large part on how that individual is tied into the larger network of social connections.

\section{THEORETICAL FRAME}

Coleman suggests that as a rational account of human behavior, trust can only be produced in informal, small, closed and homogeneous communities which are able to enforce normative sanctions [4]. Another approaching is concept of the "radius of trust." If a group's social capital produces positive externalities, the radius of trust can be larger than the group itself. It is also possible for the radius of trust to be smaller than the membership of the group. A modern society may be thought of as a series of concentric and overlapping radii of trust.Gambetta [7], has argued that scholars tend to mention trust, to allude to it as a fundamental ingredient or lubricant, an unavoidable dimension of social interaction, only to move on to deal with less intractable matters. Luhmann [8] contends that trust has never been a topic of mainstream sociology. Dasgupta [9] argues that "it is not easy to model the link between personal, groups and institutional trust. However, the link needs to be studied if we are to understand the ideal of social capital (p. 333)."'Lin [10] refers to connections as social networks "the social relationships between individual actors, groups, organizations, communities, regions and nations that serve as a resource to produce positive returns (p. 6)." The major composition of network is size (the number of ties that a person has in his personal network) and heterogeneity. The structure of a network refers to the relative density of links among people within it that facilitate the flow of information and the provision of social support to the social structure in which a person or a tie is embedded [11].Fukuyama has analyzed the link between trust, social capital and national economic success. He defined social capital as "the ability of people to work together for common purposes in groups and organizations [12]. Fukuyama [13], [14] considers the relationship 
between social capital and civic society regarding social trust. He expands the concept of social capital via "trust radius" and trust networks in his articles. From network viewpoint, the resource of many gender-based differences originates in social capital and the relation-based membership of men and woman. It is the result of cultural and social backgrounds that has caused expansive discrimination. Fukuyama argues that trust is a characteristic of systems.As Levi [15] has argued "governments provide more than the backdrop for facilitating trust among citizens; governments also influence civic behavior to the extent they elicit trust or distrust towards themselves." Stone and Hughes [16] distinguish three types of networks - informal ties with kin, families, friends, neighbors, and workmates; generalized relationships with local people, people in civic groups, and people in general; and relationships through institutions. In social resource theory, valued resources in most societies are represented by wealth, power and status [17]. At the individual level, the outcomes could include better physical and mental health, life satisfaction, wealth, power and reputation [18].

\section{RESEARCH'S LITERATURE}

Wolfe [19] argues that individual create their moral rules - that is, mutual obligations - through the social interactions they experience with others. Trust is necessary for social order and human action to continue[20]. Fox [21] also regards trust as a characteristic of social systems. He argues that trust and distrust "are embodied in the rules, roles and relations which some men impose on, or seek to get accepted by, others." Farrell and Knight [22] argue that institutions create rules, incentives and sanctions for people to behave in a trustworthy manner, thereby fostering trust. In addition, institutions can disseminate information about expected behavior to affect social beliefs about trust.

The sociological literature conceptualizes trust as either the property of individuals, social relationships, or the social system with disproportionate attention to behavior based on actions at the individual level [20]. When seen as a characteristic or property of individuals, trust is a personality variable, thereby placing emphasis on individual characteristics like feelings, emotions, and values [19]. A second perspective regards trust as a collective attribute that can be drawn upon to achieve organizational goals [20]. In the third perspective, trust as a valued public good facilitated and sustained by a social system. Putnam [23], has argued that trust within the community is what has made democracy work in northern Italy. On the individual level, you trust an individual to do something based on what you know of his disposition, his ability, his reputation and so forth not merely because he says he will do it. On the collective level, if you don't trust an agency or organization with which the individual is affiliated, you will not trust him to fulfill an agreement[24]. Some studies of trust have focused on economic growth [25]-[27], [12] and institutional development [28]-[30]. Bjørnskov [31] shows that there is significant correlation between social trust and life satisfaction in country-level regressions, and similarly, Bjørnskov [32] finds significant links in US state-level regressions. However, Ram [33] finds only a fragile role for social trust in country-level regressions for life satisfaction. Individual-level regressions all tend to support the existence of strong links between trust and measures of subjective wellbeing. Chang [34] shows that the level of social trust is positively associated with happiness using data from a survey in Taiwan. Yip et al [35] also find evidence of strong linkages between trust and life satisfaction using data collected in rural China.Adler and Kwon [36] identified that the goodwill that others have toward us is a valuable resource. Its source lies in the structure and content of the actor's social relations. Its effects flow from the information, influence, and solidarity it makes available to the actor' [36]. The modern emergence of social capital concept renewed the academic interest for an old debate in social science: the relationship between trust, social networks and the development of modern industrial society. Previous research has indicated that there is an association between social networks and a number of health outcomes[37]-[38]. Granovetter [3] has argued that social relations and the obligations inherent in them are two main sources of trust in economic life. Heliwell and Putnam [39] argue that higher average education levels help to create a climate of trust that is self-reinforcing. Various studies have been conducted on social trust in relation to age [40]-[42].

\section{CONCEPTUAl MOdeL's RESEARCH}

Putnam [23] has argued that social trust can arise from norms of reciprocity, which is similar to the creation of social capital. In this article based on Coleman, Putnam, Stone and Hughes ,Lin, Fukuyama social's theoretical view points and conceptual model, Social trust and networks of men and women are studied.

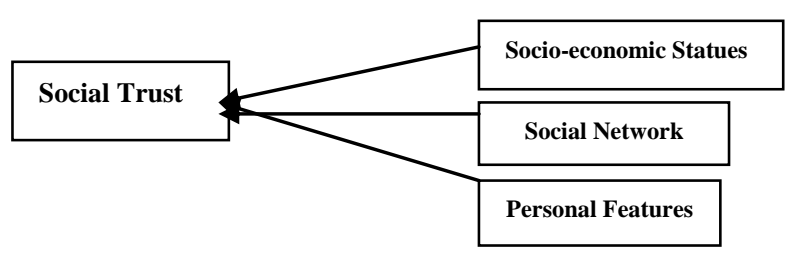

Fig. 1.Conceptual model's research

\section{A. Methodological Approach}

This research has been done through survey method in Iran in 2011. Men and women over 18 mostly residents of Esfahan form statistical community of this research. Based on sample volume formula, 300 people were questioned. Data was gathered through the questionnaires; using survey method and data collecting techniques, this article has gathered necessary data. Regarding population statistics of people, over 18 in Esfahan and sample volume formula, a sample of 300 people from 3 different districts( northern, central, southern) consisting of district 3, 6 and 14 has been considered. Method of sampling is combination of simple random and class random. Interviews were done through questionnaires.

\section{B. Statistical Methods}

In this research uses individuals as units of analysis. To analyze the relationship among variables and test hypothesis, correlative coefficient and multi variable regression have been used. Based on main indices mentioned in the conceptual definition of social trust 
network, some indicators were introduced and the evaluation of their nominal validity and reliability of each one of indices was determined regarding Corenbach Alpha coefficient.

\section{HYPOTHESIS}

There is a meaningful difference between personal features and social trust.

There is a meaningful difference between socio-economic status and trust.

There is a meaningful statistical difference between type of network and social trust.

\section{A. Theoretical and Practical Definition of Variables}

Social Trust: Trust is a social phenomena that is embodied in structures of social relations. The main characteristic of each is "confidence in or reliance on some quality or attributes of a person or thing, or the truth of a statement [43]. Giddens [6] defines trust as "confidence in the reliability of a person or system, regarding a given set of outcomes or events, where that confidence expresses a faith in the probity or love of another, or in the correctness of abstract principles."

\section{B. The Main Indicator of Social Trust and Network}

Fukuyama [12] defines trust as "the expectation that arises within a community of regular honest, and cooperative behavior, based on shared norms, on the part of other members of the community." The measures of trust consider include 'social trust' and how person in generally can be trusted in other people. Social trust is measured based on the trust in people and trust in civil generalized relations. Individual assessments of the trust in their family, neighbors, co-workers, friends and Fellow Citizen. The confidence among individuals is formed in social relationships. Membership in associations increase face-toface interactions between people.

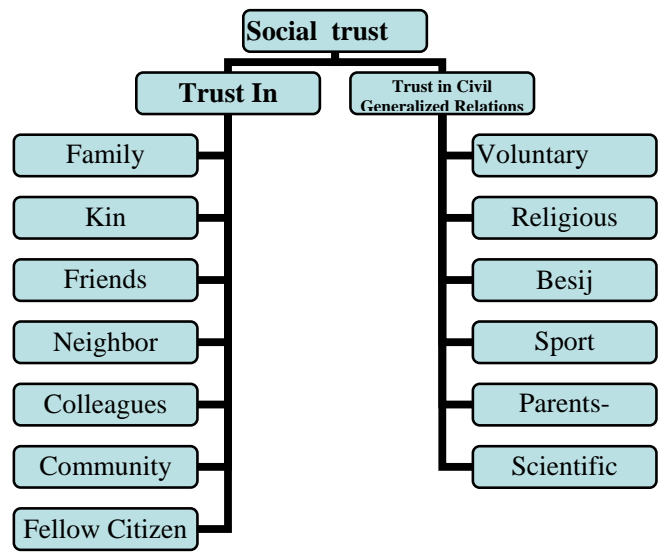

Fig. 2. The confidence among individuals is formed in social relationships.

The measurements of network includes the network combination, size, rate of network resources and diversity. Type of networks divide to emotional and supportive network.

For measures of networks based on generalized relationship with people and civic groups, membership or participant in the associations was used. The level of confidence in various institutions and group such as police, doctor, teacher. Lawyer, etc, was used as an indicator of the trust dimension of the third type of network. In this paper, networks of family, friends, neighbors and kin are measured through several indicators of people social relationships.

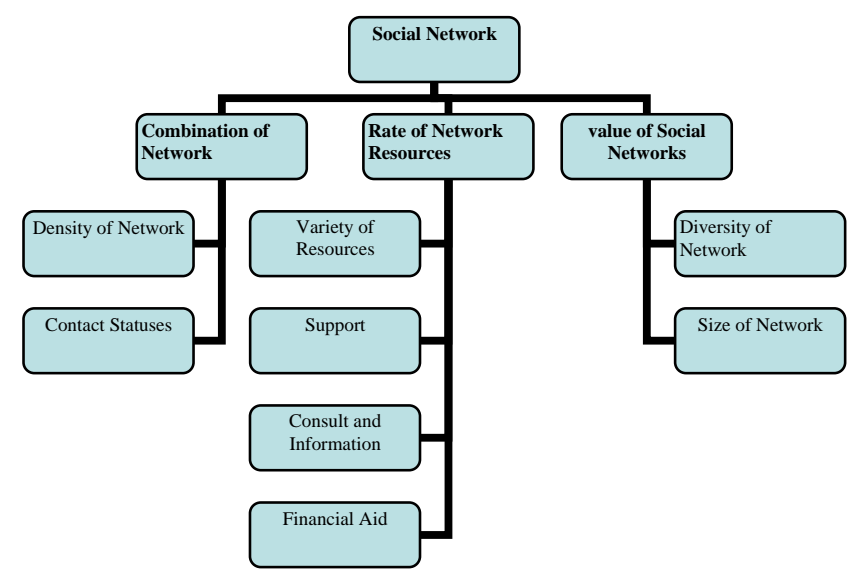

Fig. 3. Networks of family, friends, neighbors and kin are measured through several indicators of people social relationships

Measurement of social resources can be further specified as network resources and contact resources. Network resources refer to resources embedded in individual networks.

\section{FINDINGS DESCRIPTION OF VARIABLES}

A little more than half $(54 \%)$ of the respondents were women and the rest were men. The highest percentage of the respondents belonged to the age group of 20- 24 (26\%) and the lowest belonged to the age group of 40-49. Most of the respondents had a bachelor degree $(41.3 \%) .26 \%$ of the respondents had a diploma degree and $8 \%$ had an M.A and Ph.D degrees. The lowest percentage of the respondents were illiterate. $86 \%$ of the respondents were born in the city and the rest were born in the village. $56 \%$ of the respondents had a lot of family comings and goings and $40.7 \%$ had a lot of communication with their friends. $51 \%$ of the respondents had little comings and goings with their neighbors and $41 \%$ had no communication with them. The rate of social trust is high. Majority of the respondents have had level of average social trust and 128 of the respondents have had high social trust. The rate of the respondents' trust in people and civil institutes were totally high.

\section{HyPOTHESIS TESTING}

The first Hypothesis: There is a meaningful statistical difference between personal features (gender, marital status, and age) and social trust.

\section{A. Bivariate and Multivariate Analysis}

Regarding the level of significance in Leven's test, there was no possibility of using T test, therefore, non parametric test was used. Considering the level of significance the relationship between the gender and social trust is meaningful. In nominal measurement level there has been a meaningful relationship between the men and women social trust regarding the testing result and the level of significance 
(sig=./01) and V Cramers test.

TABLE I: GENDER * TRUST CROSS TABULATION

\begin{tabular}{|c|c|c|c|c|}
\hline Variables & \multicolumn{3}{|c|}{ Trust } & Total \\
\hline & Low & Average & High & \\
\hline Men & 2 & 67 & 70 & 139 \\
Women & 4 & 99 & 58 & 161 \\
Total & 6 & 166 & 128 & 300 \\
\hline
\end{tabular}

The average level of social trust for female is high compared to males. Also, based on level of significance, there is not a meaningful statistical relationship between the respondents' marital status and social trust.

In ordinal measurement level, considering the level of significance the relationship between the age and social trust is not meaningful. The older person gets the fewer contacts he has in the networks.

The Second Hypothesis: There is a significance relationship between socio-economic statues and social trust. In ordinal measurement level, regarding Kendall's tau $\mathrm{B}$ and $\mathrm{C}$ and Gamma tests, there is a meaningful statistical relationship between the respondent's level of socioeconomic statues and social trust. The hypothesis on relationship between these two variables is confirmed. Thus, second hypothesis was supported.

TABLE II: CORRELATION CONFIDENCE

\begin{tabular}{|l|l|l|}
\hline Trust & Sig & Correlation \\
\hline Gender & 0.01 & -.147 \\
\hline Age & 0.185 & \\
\hline Marital status & 0.9 & \\
\hline Socio-economic statues & 0.000 & 0.245 \\
\hline Supportive Network & 0.000 & 0.887 \\
\hline Emotional Network & 0.309 & \\
\hline
\end{tabular}

The Third Hypothesis: There is meaningful statistical difference between type of networks and social trust.

There is meaningful statistical difference between emotional network features and social capital, regarding correlation coefficient testing results (sig=./02)) having carried out the three- variable testing of gender, emotional and supportive networks and trust. Based on T test, there is a meaningful difference between supportive networks of women and men but there is no difference between emotional networks of men and women.

\section{HYPOTHESIZED AND MULTIVARIABLE REGRESSION RELATIONSHIPS}

To analyze the data, the multivariable regression has been used. Considering the results from the multivariable regression statistical analysis of social trust, equals $\mathrm{R}^{2}=0.886$. It can be concluded that the supportive networks, education and kind of job have affected the social trust. According to regression analysis, the best model with the least variable and $\mathrm{R}^{2}=0 . / 886$ is meaningful. So one can come to this conclusion that about $89 \%$ of social trust is interpreted by variables of supportive networks, education and kind of job.

\section{Discussion}

This study, using data collection of 300 people over 18 from Iran (Esfahan), has considered the effects of some factors on men and women's social trust. In this article based on Coleman, Putnam, Stone and Hughes, Lin, Fukuyama social's theoretical view points and conceptual model, Social trust and networks of men and women are studied. Produced results of multi variable analysis of this study agree with theoretical experiences. In this article, the main subject is social trust and networks. Social trust is a multi-dimensional concept that emphasizes both the quality and structure of social relationships. The conceptualization of social trust is closely linked to the social network.

According the findings of this research, There is a significant difference between gender and social trust. women's social trust is more than Men. In Wellman's research[44] this is confirmed via stating that men and women's networks are not basically different and sex differences will vanish or at least decrease providing that life events e.g. marriage, giving birth and employment be controlled.

There is a meaningful difference between social trust and supportive network of respondents. Granovetter mentions the functions and power of weak links. He believes that power is a linear combinational link of time spent on interaction, emotional intensity intimacy (mutual trust) and mutual services existing in a link [45]. Regarding the result of this research, there is difference between supportive networks of women and men but there is no difference between emotional networks of men and women. As men are involved in official occupations their networks are more formal than those of women and include mostly colleagues and less relatives. On the other hand, women's networks are less formal and include more relatives comparing men's networks. Parallel theories, also, have been utilized to depict different network compositions, believing that people have different inclinations and approaches regarding people to whom they are related and relevant network. Considering Morro's view, there are a lot of differences between men and women in their rules related to social networks. The skills and goods have an emotional value of an important source which are more accessible to women because of their focus on a private area, specially where the networks are recognized through effective links [46]. This difference included emotional and supportive sources based on network resources. Women have tendency for close and intimate links with relatives and less none family links. On the contrary, men tend mostly towards out of family links. Social networks have an increasing importance in forming the person social individuality. In this research, there is a significant difference between age and social trust. Old traditional collective structures are replaced by observable and tangible social networks. Considering the results from the multivariable regression statistical analysis of social trust, it can be concluded that the supportive networks, education and kind of job have affected the social trust. A weak link is the origin of network sources including inquiring information communication, running errands and [47]. Education and job are indices of socio - economic statues. Socio - economic statues determine chances of their lives. In other word, socio - economic statues determine rate of access individual to networks and sources. Knack and Keefer [48] found that increasing levels of general trust are 
associated with higher and more equal incomes, evidence also supported by other researchers [41], [49], [50].

Glaeser et al [51] found that highly educated individuals are more trusting than people of lower educational levels. Concerning the expansion of communications and individual contacts in communities, bringing about individual and also group benefits, nowadays, the amount of these communications, the variation of resources and protections, available to people, have considerable importance. However, there exists kind of segregation and inequality in relation-based membership of men and women. Different systems provide men and women with different ways of reaching social positions and sources, through which different networks, various communications and different kinds of cooperation are formed[52]. Family life also makes men and women's contacts with opposite sex possible and provides an opportunity of interaction for men and women, apart from their same-sex inclinations. Anyhow, because of strength of social factors and structural obligations in society, men have more opportunities of various contacts than do women[52].consequently sex differences, seemingly inherent, are result of a selfprotective system. Some important events during lifespan such as marriage and giving birth to babies possibly influence women's communication patterns. Expansion of family networks prior to none-family ones, conduct women into conditions different from men's and hinders their having expansive and useful networks like those of men, with same arrangement and combination as family links[53].

Trust is a phenomena cognition and depend on knowledge on believe. In Gidens [6] view point, in traditional society, life is based on certainly and trust, but modern human life consistent of uncertainly and so his trust probability with deprived doubt. The reason cause trust to each other is feeling of security.

In this research based on result, supportive networks, education and kind of job have affected the social trust. According the findings of this research, there is main question "Does trust rethinking in our society between women and men?

\section{REFERENCES}

[1] S. Cohen and S. D. Pressman. Positive Affect and Health. Current Directions in Psychological Science. vol. 15, pp. 122-25. [Online]. Available: http://dx.doi.org/10.1111/j.0963-7214.2006.00420.x 2006

[2] D. McCauley and K. Kuhnert, "A theoretical review and empirical investigation of employee trust in management," Public Administration Quarterly, 1992, pp. 265-284.

[3] M. Granovetter, "Economic action and social structure: The problem of embeddedness," American Journal of Sociology, vol. 91, 1985, pp. 481-510.

[4] J. S. Coleman, Foundations of Social Theory, Cambridge, MA: Belknap Press of Harvard University Press. 1990.

[5] C. T. Butts, "A Relational Event Framework for Social Action," Sociological Methodology, vol. 38, issue 1, December 2008, pp. 155200 ,

[6] A. Giddens, The Third way: The Renewal of Social Democracy, London, profile press,pp. ii, Gambetta, 1998.

[7] N. Luhmann, "Familiarity, confidence, trust: problems and alternative," in D. Gambetta, (Ed). Trust: Making and Breaking Cooperative Relations. Oxford, Blackwell, 1988.

[8] Dasgupta Partha. (2000). Trust as a Commodity. In Gambetta, Diego (ed.) Trust:Making and Breaking Cooperative Relations. Electronic edition. Department of Sociology. University of Oxford. chapter 4 pp. 49-72, [Online]. Available: http://www.sociology.ox.ac.uk/papers/ Dasgupta49-72.pdf.
[9] N. Lin, K. Cook, and R. Burt, Social Capital: Theory and Research, NY: Aldine DE Gruyter. (2001).

[10] B. Wellman and K. Frank, "Network capital in a multilevel world: getting support from personal communities," in N. Lin, K. Cook, and R. Burt, (Ed.). Social Capital: Theory and Researc, NY: Aldine DE Gruyter. 2001

[11] F. Fukayama, Trust: The Social Virtues and the Creation of Prosperity, New York: Free Press, vol. 10, pp. 27, 1995.

[12] F. Fukuyama, The great disruption: Human nature and the reconstitution of social order, London: Profile Books. 1999.

[13] H. Fukuyama, "Returns to scale and scale elasticity in data envelopment analysis," European Journal of Operational Research, vol. 125 , pp. $93-112,2000$

[14] M. Levi, "Social and unsocial capital: A review essay of Robert Putnam's Making Democracy Work," Politics and Society, vol. 24, pp. 46-55, 1996.

[15] W. Stone and J. Hughes, "Social Capital: Empirical Meaning and Measurement Validity," Research Paper No. 27. Melbourne: Australian Institute of Family Studies. 2002.

[16] L. Nan, "Social Resources and Instrumental Action," in Social Structure a Network Analysis, edited by P. V. Marsden and N. Lin. Beverly Hills, CA: Sage. 1982, pp. 131-45.

[17] L. Nan, Social Capital: A Theory of Social Structure and Action, Cambridge University Press, 2001

[18] R. N. Wolfe, "Trust, anomie, and the locus of control: alienation of US college student in 1964, 1969, 1974," Journal of Social Psychology, vol. 100, pp. 151-172, 1976.

[19] A. Misztal, Cambridge, Mass: Polity Press, 1996. VI, vol. 296, pp. 24.

[20] A. Fox, Beyond Contact: Work Power and Trust Relations, London: Faber and Faber. 1974

[21] H. Farrell and J. Knight, "Trust, institutions, and institutional change: Industrial districts and the social capital hypothesis," Politics \& Society, vol. 31, no. 4, 2003, pp. 537-566.

[22] R. D. Putnam, "The prosperous community: Social capital and pwolic life," American prospect, vol. 4, no.13, 1993, pp. 35-42.

[23] P. Dasgupta, "Trust as a commodity," in D. Gambetta Ed.. Trust: Making and Breaking Cooperative Relations. Oxford, Blackwell. 1988.

[24] Y. Algan and P. Cahuc. Inherited Trust and Growth. American Economic Review, vol. 100, pp. 2060-2092. 2010. [Online]. Available: http://dx.doi.org/10.1257/aer.100.5.2060

[25] N. Berggren, M. Elinder, and H. Jordahl, "Trust and Growth: A Shaky Relationship," Empirical Economics, vol. 35. pp. 251-274, 2008.

[26] O. C. Dincer and E. M. Uslaner, "Trust and Growth," Public Choice, vol. 142. pp. 59-67, 2010.

[27] P. Aghion, Y. Algan, P. Cahuc, and A. Shleifer. Regulation and Distrust. Quarterly Journal of Economics. vol. 125, pp. 877-921. 2010.

[28] A. Bergh and C. Bjørnskov, 2009. "Historical Trust Levels Predict Current Welfare State Design," Ratio Working Papers, no. 144.

[29] C. Bjørnskov, "How Does Social Trust Lead to Better Governance? An Attempt to Separate Electoral and Bureaucratic Mechanisms," Public Choice, vol. 144, pp. 323-46, 2010.

[30] C. Bjørnskov, "The Happy Few: Cross-Country Evidence on Social Capital and Life Satisfaction," Kyklos, vol. 56, pp. 3-16, 2003.

[31] C. Bjørnskov, "Social Capital and Happiness in the United States," Applied Research in Quality of Life, vol. 3. pp. 43-62, 2008.

[32] R. Ram, "Social Capital and Happiness: Additional Cross-Country Evidence," Journal of Happiness Studies, vol. 11, pp. 409-18, 2010.

[33] W. Chang, "Social Capital and Subjective Happiness in Taiwan," International Journal of Social Economics, vol. 36, pp. 844-68, 2009.

[34] W. Yip, S. V. Subramanian, A. D. Mitchell, D. T. Lee, J. Wang, and I. Kawachi, "Does social Capital Enhance Health and Well-Being? Evidence from Rural China," Social Science \& Medicine, vol. 64, pp. $35-49,2007$.

[35] Adler and Seok-Woo Kwon, Social Capital and Prospects For A New Concept, The Academy of Management Review.

[36] P. Bearman and K. Everett, "The structure of social protest, 19611983," Social Networks, vol. 15, 1993, pp. 171-200.

[37] Misztal Barbara, Trust in modern societies: The search for the bases of social order. Cambridge, UK: Polity, 1996.

[38] J. F. Helliwell and R. D. Putnam, "The Social Context of WellBeing," Philosophical Transactions of the Royal Society B, vol. 359, pp. 1435-46. Reprinted in F. A. Huppert, B. Keverne and N. Baylis, eds., The Science of Well-Being (London: Oxford University Press, 2005, pp. 435-59.

[39] P. Orlando, "Liberty against the democratic state: on the historical and contemporary sources of American distrust," in Democracy and Trust, ed. Mark E. Warren. Cambridge: Cambridge University Press. 1999 
[40] R. D. Putnam, "Bowling Alone: The Collapse and Revival of American Community," New York: Simon \& Schuster. (2000 Newton, K. Social capital and democracy. American Behavioral Scientist, vol. 40, no. 5 , pp. 575.

[41] Oxford English Dictionary, pp. 432, 1997.

[42] B. Wellman, Network in the Global Village, Boulder, Co: Westwood. 1999

[43] P. V. Marsden, "Interpersonal ties, social capital, and employer staffing practices," 2001

[44] N. Lin, K. Cook, and R. S. Burt, Social Capital: Theory and Research, Aldine de Gruyter, New York(eds)

[45] M. Virginia, "Conceptualising Social Capital in Relation to the WellBeingof Children and Young People: A Critical Review," The Sociological Review, vol. 47, pp. 744-765, 1999.

[46] D. Costa and M. Kahn, "Understanding the American Decline in Social Capital, 1952Đ1998Õ," Kyklos, vol. 56, no. 1, 17Đ46. 2003

[47] S. Knack and P. Keefer. 1997. Does Social Capital Have an Economic Payoff? A Cross-Country Investigation. Quarterly Journa of Economics. vol. 112. pp. 1251-88. [Online]. Available: http://dx.doi.org/10.1162/003355300555475

[48] R. Inglehart, "Trust, well-being and democracy," in Democracy and Trust, ed. Mark E. Warren, pp. 88-120. Cambridge: Cambridge University Press. 1999.

[49] P. Paxton, "Social capital and democracy: an interdependent relationship," American Sociological Review, vol. 67, pp. 254-277, 2002.

[50] E. Glaeser and David Laibson, "Jose A. Scheinkman, and Christine L. Soutter," Measuring trust. Quarterly Journal of Economics, vol. 115, 2000, pp. 811-846.

[51] B. H. Erickson and M. Kakuko, "Macro and Micro Gender Structures: Gender Stratification and Social Network in Japan and Canada," Institute for the Global Issues (ISGI seminar), March. 2005.

[52] A. Smith and K. D. Williams, "Ru there? Ostracism by cell phone text messages," Group Dynamics: Theory, Research, and Practice, vol. 8 , pp. 291-301, 2004 